\title{
Interim Analysis of Pregnancy Outcomes After Exposure to Dimethyl Fumarate in a Prospective International Registry
}

Kerstin Hellwig, MD, David Rog, MD, Christopher McGuigan, MD, Maria K. Houtchens, MD, Denise R. Bruen, NP, RN, Oksana Mokliatchouk, PhD, Filipe Branco, MS, Xiaomei Peng, PhD, * and Nicholas J. Everage, PhD

Neurol Neuroimmunol Neuroinflamm 2022;9:e1114. doi:10.1212/NXI.0000000000001114

\section{Abstract}

\section{Background and Objectives}

Oral delayed-release dimethyl fumarate (DMF) is not recommended during pregnancy and should only be used if the potential benefit justifies the potential fetal risk. Although DMF was well tolerated in clinical trials with consistent safety results in postmarketing surveillance, data are limited in pregnant women. The objective was to provide pregnancy outcomes and DMF exposure information from an interim analysis from a prospective, international registry (TecGistry; NCT01911767).

\section{Methods}

Women exposed to DMF from the first day of their last menstrual period before conception or during pregnancy were evaluated. Data were obtained at enrollment; 6-7 months' gestation; 4 weeks after estimated due date; and 4, 12, and 52 weeks after birth. Outcomes included live births, gestational size, pregnancy loss, birth defects, and infant or maternal death after delivery. Outcomes were analyzed cumulatively from October 30, 2013 (the start of TecGistry), to April $8,2020$.

\section{Results}

Of 345 enrolled patients, median (range) age was 32 (20-43) years. The mean (SD) duration of gestational weeks of DMF exposure was 4.9 (3.8). Most infants were full-term at birth ( $\mathrm{n}=$ $249 / 274 ; 91 \%)$ and of average gestational size $(\mathrm{n}=190 / 232 ; 82 \%)$. Of 351 outcomes, 277 were live births; 17 (5\%) spontaneous abortions (95\% confidence interval [CI] 2.6\%-7.1\%), including $1(<1 \%)$ molar and $1(<1 \%)$ ectopic pregnancy, were reported. There were $8(2.9 \%$ [95\% CI 1.3\%-5.6\%]) adjudicator-confirmed birth defects among the 277 live births.

\section{Discussion}

Interim results from this large registry indicate that early DMF exposure was not significantly associated with adverse pregnancy outcomes. Outcomes are consistent with previous smaller reports and with the general population.

\section{Trial Registration Information}

TecGistry; clinical trial registration number: NCT01911767.

\author{
Correspondence \\ Dr. Everage \\ nicholas.everage@biogen.com
}




\section{Glossary}

DMF = dimethyl fumarate; $\mathbf{C I}=$ confidence interval; $\mathbf{M S}=$ multiple sclerosis.

The global prevalence of multiple sclerosis (MS) is 2 and up to 4 times higher in women than in men $^{1}$; a large proportion of women with MS are of childbearing age. ${ }^{1,2}$ Delayed-release dimethyl fumarate (DMF) is recommended for the treatment of relapsing-remitting MS, but DMF is not recommended during pregnancy. DMF should be used only if clearly needed and if the potential benefit justifies the potential risk to the fetus. ${ }^{3}$ As of June 30, 2021, >535,000 patients have been treated with DMF, representing $>1,100,000$ patient-years of exposure. No risk of fetal abnormalities or adverse pregnancy outcomes has been observed in relation to DMF exposure in clinical trials, which have shown 97 of 142 (68\%) live births, 16 of 142 (11\%) spontaneous abortions, 24 of 142 (17\%) elective terminations, and 5 of 142 (4\%) preterm births (Biogen, Periodic Safety Update Report, May 24, 2018). Nonetheless, additional data are needed from the postmarketing setting. ${ }^{4}$

There is no known adverse association or mechanism of action related to DMF with pregnancy outcomes. However, a large proportion of women diagnosed with MS are of childbearing age. Therefore, a global registry was established to evaluate whether DMF exposure may affect pregnancy and infant outcomes. Study coordinating centers in 8 countries are enrolling DMF-exposed pregnant women into an ongoing, prospective, observational, international registry (TecGistry; NCT01911767) to assess pregnancy and infant outcomes. We report results from an interim analysis of the registry as of April 8, 2020.

\section{Methods}

Participants included pregnant women with MS exposed to DMF since the first day of their last menstrual period before conception or during pregnancy. Women were excluded if diagnosed with abnormalities in prenatal testing or the pregnancy outcome was known at enrollment. Specifically, the evidence of abnormalities found in an ultrasound, amniocentesis, or maternal serum alpha-fetoprotein/serum would exclude the patients. In addition, the following specific infectious diseases would exclude patients: rubella (by titer), toxoplasmosis (by screening), venereal disease research laboratory (rapid plasma screen), hepatitis B (by screening), or triple screen. Otherwise, patients were included and any other potential confounders or causes of abnormalities would be handled analytically. The number of pregnancy outcomes needed to detect a prevalence risk ratio of 2.9 with $80 \%$ power was 300. Evaluations consisted of live births (premature birth $[<37$ weeks] and full-term birth); pregnancy loss (elective or therapeutic pregnancy terminations, spontaneous abortions, and fetal death, including still birth); ectopic and molar pregnancies, birth defects, or congenital anomalies (including minor anomalies) occurring at age $\leq 52$ weeks; any infant death occurring at age $\leq 52$ weeks; and any maternal death occurring $\leq 12$ weeks after delivery. Data were collected at enrollment; 6-7 months of gestation; 4 weeks after estimated delivery date; and 4, 12, and 52 weeks after birth. No information on breastfeeding with DMF or associated outcomes were collected. Outcomes were analyzed cumulatively from October 30, 2013 (the start of TecGistry), to April 8, 2020. The methods used to increase enrollment included increasing the number of coordinating centers, ensuring internal follow-up on pharmacovigilance reports as permitted by local legislation, and improving digital and social outreach to generate greater awareness of the registry in accordance with local guidance and laws.

Potential birth defects were adjudicated by an external teratology expert and classified according to both the Metropolitan Atlanta Congenital Defects Program and/or the European network for the surveillance of congenital anomalies schemas. Gestational size was classified based on the World Health Organization or country-specific growth charts as small (birth weights $<2,500 \mathrm{~g}$ ), appropriate (birth weights 2,500-4,000 g), or large (birth weights $>4,000 \mathrm{~g}$ ). Percentages associated with gestational age and size were based on births with available data. This interim analysis was descriptive in nature. The prevalence of birth defects and 95\% confidence intervals (CIs) for the registry population were calculated for this interim analysis. The ClopperPearson exact CIs were implemented.

\section{Standard Protocol Approvals, Registrations, and Patient Consents}

Participating physicians obtained centralized and/or local ethics committee approval of the protocol, informed consent form, and other required study documents before starting the study. The study was conducted in accordance with the International Conference on Harmonisation and Good Pharmacovigilance Practices guidelines. In accordance with the Declaration of Helsinki, strict respect was given to the patients' privacy; physical, mental, and social integrity; and confidentiality of personal information.

Patient consent (written or verbal per local regulations) was obtained by the reporting healthcare provider, investigator, or coordinating center (if permitted by local regulations) before the patient's enrollment in the registry. If the patient was a minor, written consent was obtained from the parent or legal guardian. A release of medical information was obtained from the patient to permit the coordinating center or reporting healthcare provider to contact healthcare providers related to 
the pregnancy (e.g., the patient's obstetric health care provider). A release of medical information was also obtained by the enrolling healthcare provider from the parent or the infant's personal representative so that the coordinating center or reporting healthcare provider could contact the pediatric healthcare provider.

\section{Data Availability}

This trial is registered on ClinicalTrials.gov (NCT01911767). The data sets generated during this study are available on request through the Biogen Data Request Portal (biogenclinicaldatarequest.com).

\section{Results}

Of 345 enrolled patients in this pregnancy registry, there were 351 known or anticipated outcomes (Figure): 243 from Germany, 65 from the United States, 16 from the United Kingdom, 9 from Italy, 8 from Australia, and 2 each from Canada and Ireland. Mean (SD) gestational week of enrollment was 11.9 (8.1). Earliest DMF exposure occurred in the first $(>99 \% ; 341 / 342)$ and second $(<1 \% ; 1 / 342)$ trimesters in the 342 women with a known exposure date (Table 1). Of 351 observed or expected pregnancy outcomes, 17 (5\%) spontaneous abortions, including 1 ectopic and 1 molar pregnancy, were reported (Table 2). One neonatal death was reported, and no maternal or perinatal deaths were reported.

The median (range) duration of gestational DMF exposure was 5 weeks (0-40), and more than $99 \%$ of pregnancies were only exposed to disease-modifying therapy in the first trimester (Table 1). There were 277 live births; of these, 7 were from 4 sets of twin pregnancies. Of live births with known results, most infants were full-term at birth $(n=249 / 274$; $91 \%)$ and 25 (9\%) were premature. Of the 232 infants with neonatal weight data, 26 (11\%) were classified as small, $190(82 \%)$ as appropriate, and $16(7 \%)$ as large. Of 277 live births, there were $8(2.9 \%$ [95\% Clopper-Pearson exact CI $1.3 \%-5.6 \%]$ ) confirmed birth defects (Table 2).

Figure Patient Disposition

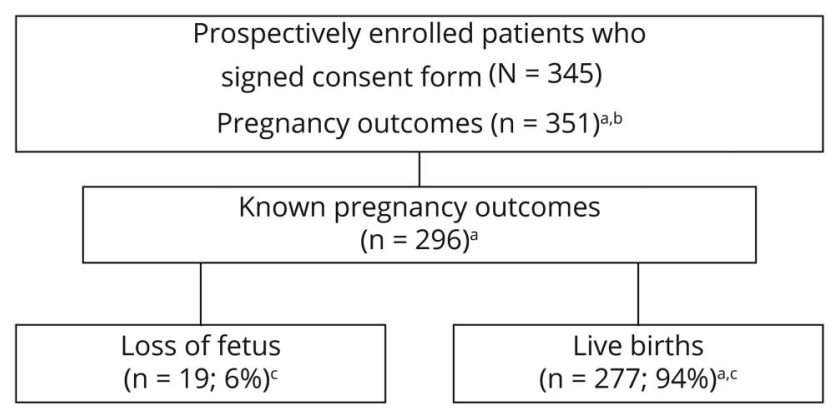

a Some pregnancies resulted in multiple (twin) births. ${ }^{b}$ Known or anticipated outcomes; missing patients may have known pregnancy outcomes but further follow-up is in progress or not yet complete. 'Percentages based on births with available birth status $n=296$ because 1 patient had missing data.
Table 1 Patient Characteristics at the Time of Enrollment and DMF Exposure

\begin{tabular}{|c|c|}
\hline Characteristic & All patients $(\mathrm{N}=345)$ \\
\hline Median (range) age, y & $32(20-43)$ \\
\hline Median (range) education, $\mathrm{y}$ & $14(9-23)$ \\
\hline \multicolumn{2}{|l|}{ Employment status, n (\%) ${ }^{a}$} \\
\hline Full-time & $173(53)$ \\
\hline Part-time & $90(27)$ \\
\hline Unemployed & $66(20)$ \\
\hline \multicolumn{2}{|l|}{$\begin{array}{l}\text { Earliest trimester of DMF } \\
\text { exposure, } \mathrm{n}(\%)^{\mathrm{b}}\end{array}$} \\
\hline First & 341 (>99) \\
\hline Second & $1(<1)$ \\
\hline Third & 0 \\
\hline \multicolumn{2}{|l|}{ Gestational wk at enrollment ${ }^{c}$} \\
\hline Mean (SD) & $11.9(8.1)$ \\
\hline Median (range) & $9(0.0-39.3)$ \\
\hline \multicolumn{2}{|c|}{$\begin{array}{l}\text { Duration of gestational weeks of } \\
\text { DMF exposure }^{c}\end{array}$} \\
\hline Mean (SD) & $4.9(3.8)$ \\
\hline Median (range) & $5(0-40)$ \\
\hline \multicolumn{2}{|c|}{$\begin{array}{l}\text { Abbreviation: } \mathrm{DMF}=\text { delayed-release dimethyl fumarate. } \\
a n=329 . \\
{ }^{b} n=342 . \\
{ }^{c} n=344 .\end{array}$} \\
\hline
\end{tabular}

Eighty-six percent $(232 / 271)$ of women indicated they breastfed their infants at any time after birth.

\section{Discussion}

Interim results from this large, international registry indicate that DMF exposure in the first trimester was not significantly associated with adverse pregnancy outcomes. The proportion of spontaneous abortions is less than that reported in MS clinical trials $(8 \%)^{4}$ and in the general US population $(12 \%-16 \%){ }^{5}$ Compared with the $3 \%$ of birth defects reported in the registry, birth defects are detected in $4 \%$ of people with $\mathrm{MS}^{6}$ and in $2 \%-5 \%$ of the general population. ${ }^{7}$ The prevalence of ventricular septal defect is estimated to range from 192 to 1,045 per 100,000 live births, ${ }^{8-10}$ whereas the prevalence in this registry was 722 per 100,000 live births.

Most women indicated they breastfed their infants. Very low excretion of DMF in breast milk has been demonstrated by 2 recent case reports. ${ }^{11}$ This is currently under investigation.

There are several limitations to this analysis. At the time of this data cut and analysis, 300 pregnancy outcomes (the targeted 
Table 2 Incidences of Pregnancy and Infant Outcomes

\begin{tabular}{|c|c|}
\hline Maternal and fetal deaths & Outcomes, n (\%) \\
\hline Maternal death $(N=351)$ & 0 \\
\hline \multicolumn{2}{|l|}{ Fetal deaths $(N=296)^{a}$} \\
\hline $\begin{array}{l}\text { Elective or therapeutic pregnancy } \\
\text { termination }\end{array}$ & 0 \\
\hline Loss of fetus & $19(6)$ \\
\hline Spontaneous abortion, $(95 \% \mathrm{Cl})^{\mathrm{b}}$ & $17(6),(2.6,7.1)$ \\
\hline Ectopic pregnancy & $1(<1)$ \\
\hline Molar pregnancy & $1(<1)$ \\
\hline Still birth ( $\geq 28$ wk of gestation) & $1(<1)$ \\
\hline Unknown, pending further follow-up & $1(<1)$ \\
\hline Infant deaths and birth defects $(N=277)$ & Outcomes, n (\%) \\
\hline Neonatal death (occurring <28 d of life) & $1(<1)^{c}$ \\
\hline $\begin{array}{l}\text { Perinatal death (occurring } \geq 28 d \text { to } \\
<12 \text { wk of life) }\end{array}$ & 0 \\
\hline Infant death (occurring $\geq 12-52$ wk of life) & 0 \\
\hline Adjudicator-confirmed birth defects, n (\%) & $8(3)^{d}$ \\
\hline Ventricular septal defect & 2 \\
\hline Congenital hydronephrosis & 1 \\
\hline $\begin{array}{l}\text { Premature newborn with multiple } \\
\text { birth defects }\end{array}$ & 1 \\
\hline Pyloric stenosis & 1 \\
\hline Transposition of the great vessels & 1 \\
\hline $\begin{array}{l}\text { Unilateral developmental dysplasia } \\
\text { of the hip }\end{array}$ & 1 \\
\hline Ureter duplication & 1 \\
\hline \multicolumn{2}{|c|}{$\begin{array}{l}\text { a Percentages in this category based on based on pregnancies with known } \\
\text { outcomes. } \\
\text { b Spontaneous abortion was defined as any loss of a fetus because of natural } \\
\text { causes at }<22 \text { weeks of gestation. } \\
\text { 'The infant was born with genetic defect and multiple anomalies. } \\
\text { 'For the specified defects of ventral septal defect, pyloric stenosis, trans- } \\
\text { position of the great vessels, congenital hydronephrosis, hip dysplasia, } \\
\text { ureter duplication, and multiple potential anomalies, particular studies in } \\
\text { the population live-born to mothers with multiple sclerosis were not } \\
\text { available. } \\
\text { e Multiple defects applied to } 1 \text { infant (transposition and patent ductus } \\
\text { arteriosus). }\end{array}$} \\
\hline
\end{tabular}

number of patients needed to detect a prevalence risk ratio of 2.9 with $80 \%$ power, assuming an expected prevalence of birth defects of $2.2 \%$ ) had not been observed, limiting the potential to draw final conclusions. Subsequent enrollment and follow-up of pregnancies will enable more detailed and robust analyses. Most exposure occurred in the first trimester with only a single pregnant woman and fetus exposed in the second trimester, suggesting minimal exposure to DMF during pregnancy and in utero in this registry. Thus, limited conclusions can be made about long-term DMF exposure during pregnancy or in utero. The results are also limited by the potential for underestimation of spontaneous abortions. Although TecGistry is an international registry, $70 \%$ of participants are from Germany, thus potentially limiting the transferability of these results to other countries.

Interim results from this large, international registry indicate that DMF exposure in the first trimester was not significantly associated with adverse pregnancy outcomes. The outcomes are consistent with previous reports of smaller groups of patients. ${ }^{4,5}$ Ongoing recruitment to this registry will allow the publication of outcomes up to 1 year of age and provide essential information on pregnancy outcomes among women exposed to DMF during pregnancy.

\section{Acknowledgment}

This study was sponsored by Biogen (Cambridge, MA). Cynthia C. Jones of Biogen (Cambridge, MA) was an integral part of the registry team and provided initial analysis and interpretation of the interim registry results. Gabrielle Knafler, $\mathrm{PhD}$, and Karen Spach, $\mathrm{PhD}$, of Excel Scientific Solutions (Fairfield, CT) provided initial editing support based on a draft from authors and incorporated author comments during revisions, and Nathaniel Hoover from Excel Scientific Solutions copyedited and styled the manuscript per journal requirements.

\section{Study Funding}

This study was sponsored by Biogen (Cambridge, MA). Funding for writing and editorial support was provided by Biogen.

\section{Disclosure}

K. Hellwig reports scientific advisory boards for Bayer, Biogen, Merck, Novartis, Roche, Sanofi, and Teva; speaker honoraria and research support from Bayer, Biogen, Genzyme, Merck, Novartis, Sanofi, and Teva; and support for congress participation from Bayer, Biogen, Genzyme, Merck, Roche, and Teva. D. Rog reports consulting fees from Biogen, Bristol Myers Squibb, Celgene, Hikma, MedDay, Merck Serono, Novartis, Roche, Sanofi, and Teva Neuroscience; research support from Actelion, Biogen, Merck Serono, Novartis, Sanofi, Teva Neuroscience, and TG Therapeutics; and speaker fees from Biogen, Merck Serono, Novartis, Roche, Sanofi, and Teva Neuroscience. C. McGuigan reports honoraria for consultancy work and/or research funding from Actelion, Biogen, Merck, Novartis, Roche, Sandoz, and Sanofi-Genzyme. M.K. Houtchens reports scientific advisory boards for Biogen, Merck, Novartis, Roche, Sanofi, and Teva and research support from Biogen, Genzyme, Merck, and Sanofi. D.R. Bruen reports scientific advisory boards for Biogen, Celgene, EMD Serono, Genentech, Novartis, and Sanofi-Genzyme. O. Mokliatchouk, F. Branco, X. Peng, and N.J. Everage are employees of and hold stock/stock options in Biogen. Go to Neurology.org/NN for full disclosures.

\section{Publication History}

Received by Neurology: Neuroimmunology \& Neuroinflammation March 30, 2021. Accepted in final form October 14, 2021. 
Appendix Authors

\begin{tabular}{|c|c|c|}
\hline Name & Location & Contribution \\
\hline $\begin{array}{l}\text { Kerstin } \\
\text { Hellwig, MD }\end{array}$ & $\begin{array}{l}\text { Neurologic Clinic, } \\
\text { University of Bochum, } \\
\text { Germany }\end{array}$ & $\begin{array}{l}\text { Drafting/revision of the } \\
\text { manuscript for content, } \\
\text { including medical writing for } \\
\text { content, major role in the } \\
\text { acquisition of data, and } \\
\text { analysis or interpretation of } \\
\text { data }\end{array}$ \\
\hline David Rog, MD & $\begin{array}{l}\text { Manchester Centre for } \\
\text { Clinical Neurosciences, } \\
\text { Salford Royal NHS } \\
\text { Foundation Trust, United } \\
\text { Kingdom }\end{array}$ & $\begin{array}{l}\text { Drafting/revision of the } \\
\text { manuscript for content, } \\
\text { including medical writing for } \\
\text { content, major role in the } \\
\text { acquisition of data, and analysis } \\
\text { or interpretation of data }\end{array}$ \\
\hline $\begin{array}{l}\text { Christopher } \\
\text { McGuigan, MD }\end{array}$ & $\begin{array}{l}\text { Department of Neurology, } \\
\text { St. Vincent's University } \\
\text { Hospital \& University } \\
\text { College, Dublin, Ireland }\end{array}$ & $\begin{array}{l}\text { Drafting/revision of the } \\
\text { manuscript for content, } \\
\text { including medical writing for } \\
\text { content, major role in the } \\
\text { acquisition of data, and analysis } \\
\text { or interpretation of data }\end{array}$ \\
\hline $\begin{array}{l}\text { Maria K. } \\
\text { Houtchens, } \\
\text { MD }\end{array}$ & $\begin{array}{l}\text { Partners MS Center, } \\
\text { Brigham and Women's } \\
\text { Hospital, Harvard Medical } \\
\text { School, Boston, MA }\end{array}$ & $\begin{array}{l}\text { Drafting/revision of the } \\
\text { manuscript for content, } \\
\text { including medical writing for } \\
\text { content, and major role in } \\
\text { the acquisition of data }\end{array}$ \\
\hline $\begin{array}{l}\text { Denise R. } \\
\text { Bruen, NP, RN }\end{array}$ & $\begin{array}{l}\text { Adult Neurology Clinic, } \\
\text { Charlottesville, VA }\end{array}$ & $\begin{array}{l}\text { Drafting/revision of the } \\
\text { manuscript for content, } \\
\text { including medical writing for } \\
\text { content, major role in the } \\
\text { acquisition of data, and } \\
\text { study concept or design }\end{array}$ \\
\hline $\begin{array}{l}\text { Oksana } \\
\text { Mokliatchouk, } \\
\text { PhD }\end{array}$ & Biogen, Cambridge, MA & $\begin{array}{l}\text { Analysis or interpretation of } \\
\text { data }\end{array}$ \\
\hline $\begin{array}{l}\text { Filipe Branco, } \\
\text { MS }\end{array}$ & Biogen, Cambridge, MA & $\begin{array}{l}\text { Drafting/revision of the } \\
\text { manuscript for content, } \\
\text { including medical writing for } \\
\text { content, and analysis or } \\
\text { interpretation of data }\end{array}$ \\
\hline
\end{tabular}

Appendix (continued)

\begin{tabular}{lll}
\hline Name & Location & Contribution \\
\hline $\begin{array}{l}\text { Xiaomei Peng, } \\
\text { PhD }\end{array}$ & Biogen, Cambridge, MA & $\begin{array}{l}\text { Major role in the acquisition } \\
\text { of data and analysis or } \\
\text { interpretation of data }\end{array}$ \\
\hline $\begin{array}{l}\text { Nicholas J. } \\
\text { Everage, PhD }\end{array}$ & Biogen, Cambridge, MA & $\begin{array}{l}\text { Drafting/revision of the } \\
\text { manuscript for content, } \\
\text { including medical writing for } \\
\text { content, major role in the } \\
\text { acquisition of data, study } \\
\text { concept or design, and } \\
\text { analysis or interpretation of } \\
\text { data }\end{array}$ \\
\hline
\end{tabular}

\section{References}

1. Walton C, King R, Rechtman L, et al. Rising prevalence of multiple sclerosis worldwide: insights from the Atlas of MS. Mult Scler. 2020;26(14): 1816-1821.

2. Wallin MT, Culpepper WJ, Campbell JD, et al. The prevalence of MS in the United States: a population-based estimate using health claims data. Neurology. 2019;92(10): e1029-e1040.

3. European Medicines Agency. Annex I Summary of Product Characterisitcs [online]. Accessed $26 \mathrm{March}, 2021$. ema.europa.eu/en/medicines/human/EPAR/tecfidera\#productinformation-section

4. Gold R, Phillips JT, Havrdova E, et al. Delayed-release dimethyl fumarate and pregnancy: preclinical studies and pregnancy outcomes from clinical trials and postmarketing experience. Neurol Ther. 2015;4(2):93-104.

5. Lang K, Nuevo-Chiquero A. Trends in self-reported spontaneous abortions: 19702000. Demography. 2012;49(3):989-1009.

6. Ramagopalan SV, Guimond C, Criscuoli M, et al. Congenital abnormalities and multiple sclerosis. BMC Neurol. 2010;10:115.

7. Centers for Disease Control and Prevention (CDC). Update on overall prevalence of major birth defects-Atlanta, Georgia, 1978-2005. MMWR Morb Mortal Wkly Rep. 2008;57(1):1-5.

8. Cresti A, García-Fernández MA, De Sensi F, et al. Prevalence of auricular thrombosis before atrial flutter cardioversion: a 17-year transoesophageal echocardiographic study. Europace. 2016;18(3):450-456.

9. EUROCAT. Key Public Health Indicators [online]. Accessed July 25, 2020. eu-rdplatform.jrc.ec.europa.eu/eurocat/eurocat-data/key-public-health-indicators

10. Su XJ, Yuan W, Huang GY, Olsen J, Li J. Paternal age and offspring congenital heart defects: a national cohort study. PLoS One. 2015;10(3):e0121030.

11. Ciplea AI, Datta P, Rewers-Felkins K, et al. Dimethyl fumarate transfer into human milk. Ther Adv Neurol Disord. 2020;13:1756286420968414. 


\title{
Neurology \\ Neuroimmunology \& Neuroinflammation
}

\author{
Interim Analysis of Pregnancy Outcomes After Exposure to Dimethyl Fumarate in a \\ Prospective International Registry \\ Kerstin Hellwig, David Rog, Christopher McGuigan, et al. \\ Neurol Neuroimmunol Neuroinflamm 2022;9; \\ DOI 10.1212/NXI.0000000000001114
}

This information is current as of November 23, 2021

\section{Updated Information \& \\ Services}

References

Subspecialty Collections

Permissions \& Licensing

Reprints including high resolution figures, can be found at:

http://nn.neurology.org/content/9/1/e1114.full.html

This article cites 9 articles, 0 of which you can access for free at: http://nn.neurology.org/content/9/1/e1114.full.html\#\#ref-list-1

This article, along with others on similar topics, appears in the following collection(s):

All Demyelinating disease (CNS)

http://nn.neurology.org//cgi/collection/all_demyelinating_disease_cns

Multiple sclerosis

http://nn.neurology.org//cgi/collection/multiple_sclerosis

Neonatal

http://nn.neurology.org//cgi/collection/neonatal

Information about reproducing this article in parts (figures,tables) or in its entirety can be found online at:

http://nn.neurology.org/misc/about.xhtml\#permissions

Information about ordering reprints can be found online:

http://nn.neurology.org/misc/addir.xhtml\#reprintsus

Neurol Neuroimmunol Neuroinflamm is an official journal of the American Academy of Neurology.

Published since April 2014, it is an open-access, online-only, continuous publication journal. Copyright

Copyright $\odot 2021$ The Author(s). Published by Wolters Kluwer Health, Inc. on behalf of the American

Academy of Neurology.. All rights reserved. Online ISSN: 2332-7812.

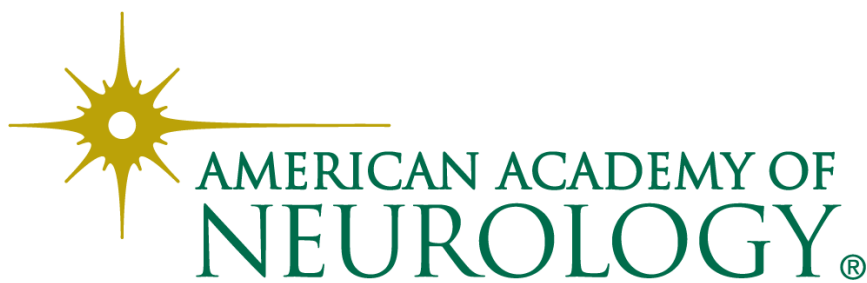

